https://doi.org/10.15407/scine17.04.033

KOVTUN, Yu. V. (https://orcid.org/0000-0003-4948-0896),

GLAZUNOV, G. P. (https://orcid.org/0000-0002-8895-927X),

MOISEENKO, V.E. (https://orcid.org/0000-0001-9431-5617),

MAZNICHENKO, S. M. (https://orcid.org/0000-0002-4548-370X),

BONDARENKO, M. N. (https://orcid.org/0000-0001-5783-9788),

KONOTOPSKIY, A. L. (https://orcid.org/0000-0002-1622-6376),

SIUSKO, Y. V. (https://orcid.org/0000-0002-0789-7100),

TARASOV, I. K. (https://orcid.org/0000-0001-8025-645X),

SHAPOVAL, A. N. (https://orcid.org/0000-0002-4521-7217),

LOZIN, A. V. (https://orcid.org/0000-0002-8423-0078),

KOROVIN, V. B. (https://oreid.org/0000-0001-8677-1073),

KRAMSKOY, E. D. (https://orcid.org/0000-0002-3621-468X),

KOZULYA, M. M. (https://orcid.org/0000-0003-3854-7047),

BARON, D. I. (https://orcid.org/0000-0001-5971-1243),

LISTOPAD, V. M. (https://orcid.org/0000-0001-7768-0495),

and KRASIUK, A. Yu. (https://orcid.org/0000-0003-4347-310X)

Institute of Plasma Physics of Kharkov Institute of Physics and Technology, National Science Center

1, Akademicheskaya St., Kharkiv, 61108, Ukraine,

+380 573353530 , garkusha@ipp.kharkov.ua

\title{
DEVELOPMENT OF TECHNOLOGY FOR VACUUM SURFACE CONDITIONING BY RF PLASMA DISCHARGE COMBINED WITH DC DISCHARGE
}

Introduction. It is important to decrease light and heavy impurities influxes towards the plasma volume during the high temperature plasma experiments in fusion devices. This is why the conditioning of the wall inner vacuum surfaces is a basic part of the fusion device operation.

Problem Statement. The conventional inner vacuum chamber surface conditioning methods has a significant drawback: sputtering materials in a vacuum chamber. The inner vacuum surfaces can be also conditioned with radio-frequency (RF) discharge plasma, but the conditioning effectiveness is limited by low ion energy.

Purpose. The purpose of this research is to develop vacuum surface conditioning technology by the radio frequency plasma combined with $D C$ discharge.

Citation: Kovtun, Yu. V., Glazunov, G. P., Moiseenko, V. E., Maznichenko, S. M., Bondarenko, M. N., Konotopskiy, A. L., Siusko, Y. V., Tarasov, I. K., Shapoval, A. N., Lozin, A. V., Korovin, V. B., Kramskoy, E. D., Kozulya, M. M., Baron, D. I., Listopad, V. M., Krasiuk, A. Yu. Development of Technology for Vacuum Surface Conditioning by RF Plasma Discharge Combined with DC Discharge. Sci. innov. 2021. V. 17, no. 4. P. 33-43. https://doi.org/10.15407/scine17.04.033 
Materials and Methods. The noncontact passive method of optical plasma spectroscopy has been used to estimate ion plasma composition. The stainless steel outgassing has been determined in situ with the thermodesorption probe method. The sputtering of the samples has been measured with the weight loss method.

Results. The studies of combined discharge have shown that: the anode voltage of combined discharge is lower than in case of the glow discharge; the stainless steel 12Kh18N10T erosion coefficient is about 1.5 times less in the case of combined discharge than in the glow one; the thermal desorption diagnostic of wall conditions in the DSM-1 experimental device has shown better efficiency with the combined discharge as compared with the glow discharge. The proposed technology is an original one and has no analogs.

Conclusions. The reported research results have shown good prospects for the combined discharge usage for plasma walls conditioning and opportunities for using the combined discharge technology for big fusion machines.

Keyw ords: plasma, glow discharge, microwave discharge, stellarator, and vacuum.

Decreasing light and heavy impurities influx to plasma is one of the important problems of experimental high-temperature plasma research for controlled nuclear fusion. The contaminations of vacuum chamber inner walls facing to plasma deteriorate the plasma parameters, increase the energy losses and even lead to radiation collapses and disruptions. This is a reason why the conditioning of inner vacuum surfaces is a basic part of fusion device operation, in particular in the case of international experimental fusion reactor ITER $[1,2]$ and future fusion reactors. So, developing the scenarios for effective inner vacuum surface conditioning is a relevant problem.

Different conditioning methods are used in hightemperature plasma confinement devices [3-5]. There are different discharge types for plasma creation, depending on conditioning conditions, both impulse and continuous ones: the Taylor discharge [3-5]; the glow discharge [3-7] and different types of radio frequency (RF) discharges [6-16] within different frequency ranges (electron cyclotron frequency [6-8], ion cyclotron frequency [8-10], and very high frequency (VHF) [14-16]).

The glow discharge is the most wide-used wall conditioning technology [3-7]. However, this technology has a considerable disadvantage that is sputtering of materials during discharge cleaning. In the glow discharge plasma, the energy of ions hitting the wall is higher than the material sputtering threshold. This leads to negative consequences, such as damage of inner devices and deposition of metal films on the inner walls of the vacuum chamber and on the equipment inside it. These negative effects weaken when the glow discharge takes place in the atmosphere of gases with a low atomic mass, for example, helium and hydrogen. The sputtering rate decreases, but the phenomenon is not fully eliminated.

The RF and VHF discharge plasma wall conditioning is competitive to the glow discharge conditioning technology [11-16]. The RF discharge plasma conditioning methods without magnetic field and in weak magnetic field have been developed at IPP NSC KIPT and used for vacuum chamber wall conditioning of stellarators (torsatrons) Uragan-2M and Uragan-3M. The complicated physical processes of the wave propagation and the physical and chemical plasma-neutral gas and plasma-wall interaction run in RF discharges. The ion collision with the wall is one of these processes. They may be used for walls conditioning, but their effectiveness is limited by low ion energy.

The combination of RF and glow discharge, so called RG-discharge (combined RF-glow discharge), has been also used (see [3-5]). This technology was developed and introduced at the TEXTOR tokamak. Those experiments used three RF systems with a power of $250 \mathrm{~W}$ at a frequency of $13.6 \mathrm{MHz}$, a DC source power of up to $10 \mathrm{~kW}$, and a voltage of up to $1.1 \mathrm{kV}$. Because of high anode voltage, this technology has the same disadvantage of sputtering as in the case of the glow discharge.

The sputtering rate may be reduced by lowering the ion energy. The appropriate ion energy 
ranges within $10-50 \mathrm{eV}$, where it is less than the sputtering threshold, but is sufficient to destroy the contaminating films on the vacuum surfaces. This energy range may be realized neither in the $\mathrm{RF}$, nor in the glow discharges. Electric biasing may be a possible way to control ion energy in RF discharge. The discharge voltage may be reduced in the glow discharge to get lower ion energy, which leads to decreasing ion flux to the cathode. However, voltage may be lowered to a certain threshold when the discharge cannot be sustained any longer. Additional microwave power may be fed into glow discharge plasma to decrease discharge voltage and to create combined discharge in such a way. The wall conditioning effectiveness is expected not to worsen during a combined discharge as compared with the conventional one, and wall material erosion rate should be lower than in the case of glow discharge.

It should be noted, that the first interest to the combined discharge was associated with the use of gas-discharge diodes as microwave power probes [17-19]. That research was carried out with rather small gas-discharge devices (the volume was up to several cubic centimeters). The external electric field influence upon electrode microwave discharge (volume $\sim 10^{3} \mathrm{~cm}^{3}$ ) has been studied in [20, 21] where the possibility to control charge particle fluxes to the discharge chamber surface has been shown. In general, there have been few studies of combined glow-microwave discharges, and data collected in them have been still fragmented.

The purpose of this research is to study combined glow-RF discharge in terms of vacuum surfaces conditioning. The research results have been implemented in Uragan-2M stellarator.

\section{RF and DC Combined Discharge Research}

The experimental research on the RF and DC combined discharge has been carried out at the DSM-1 (the diagnostic stand for materials) device that has a cylindrical chamber [22-25]. It is used for material erosion studies in crossed electrical and magnetic fields [22-25]. The scheme and picture of the device is shown in Fig. 1. Its vacuum cham-

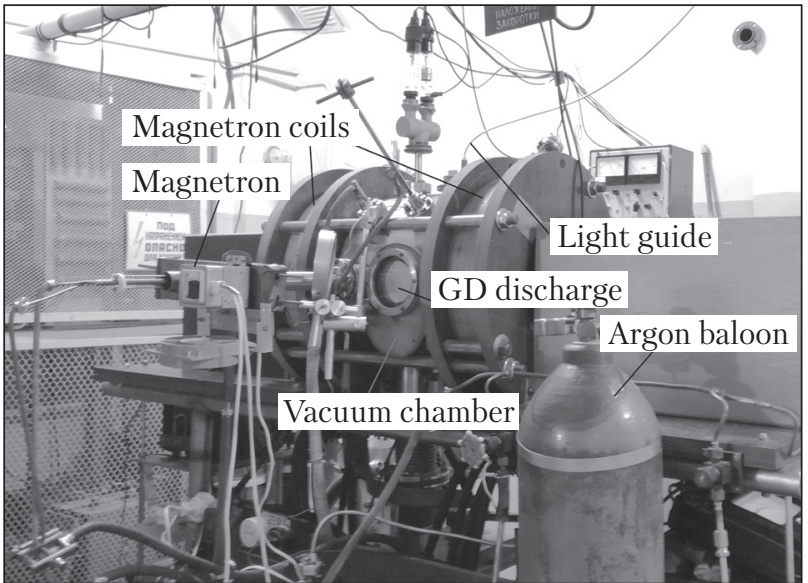

$a$

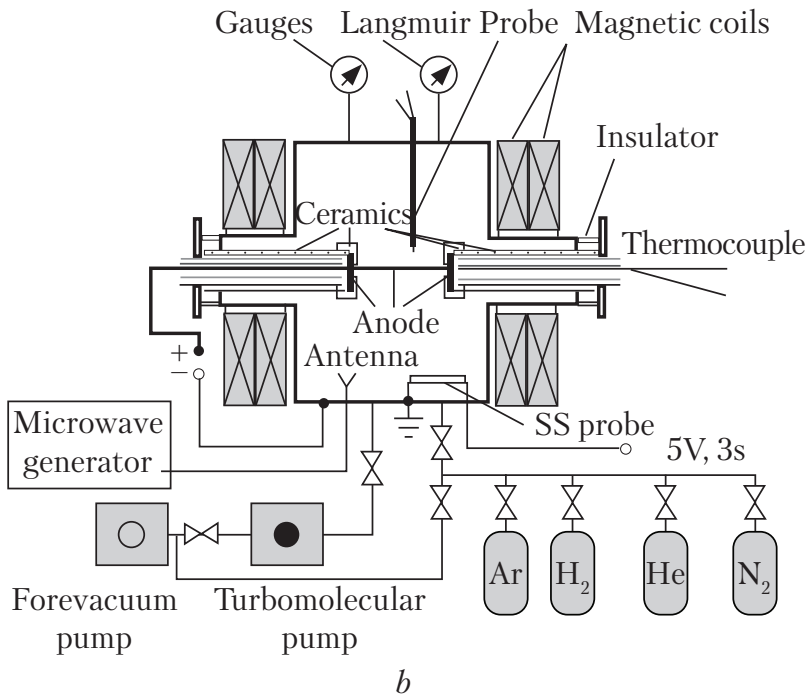

Fig. 1. Photo ( $a$ ) and scheme ( $b$ ) of DSM-1 device

ber has a volume of $0.35 \mathrm{~m}^{3}$ and is made of stainless steel $12 \mathrm{Kh} 18 \mathrm{~N} 10 \mathrm{~T}$. The area of the inner vacuum chamber wall surface is $\approx 0.5 \mathrm{~m}^{2}$. The pumping system includes one high vacuum turbo-molecular pump TMN-500 with a pumping rate of $500 \mathrm{l} / \mathrm{s}$ and one fore-vacuum pump NVR-5 with a pumping rate of $5 \mathrm{l} / \mathrm{s}$.

The device has been upgraded for experiments with glow and combined discharges. A Langmuir probe, two optical windows for spectroscopic measurements, a thermal desorbtion probe, and a watercooled feed-through for microwave antenna have been installed on DSM-1. Magnetron with a power of $0.8 \mathrm{~kW}$ and a frequency of $2.45 \mathrm{GHz}$ is used 

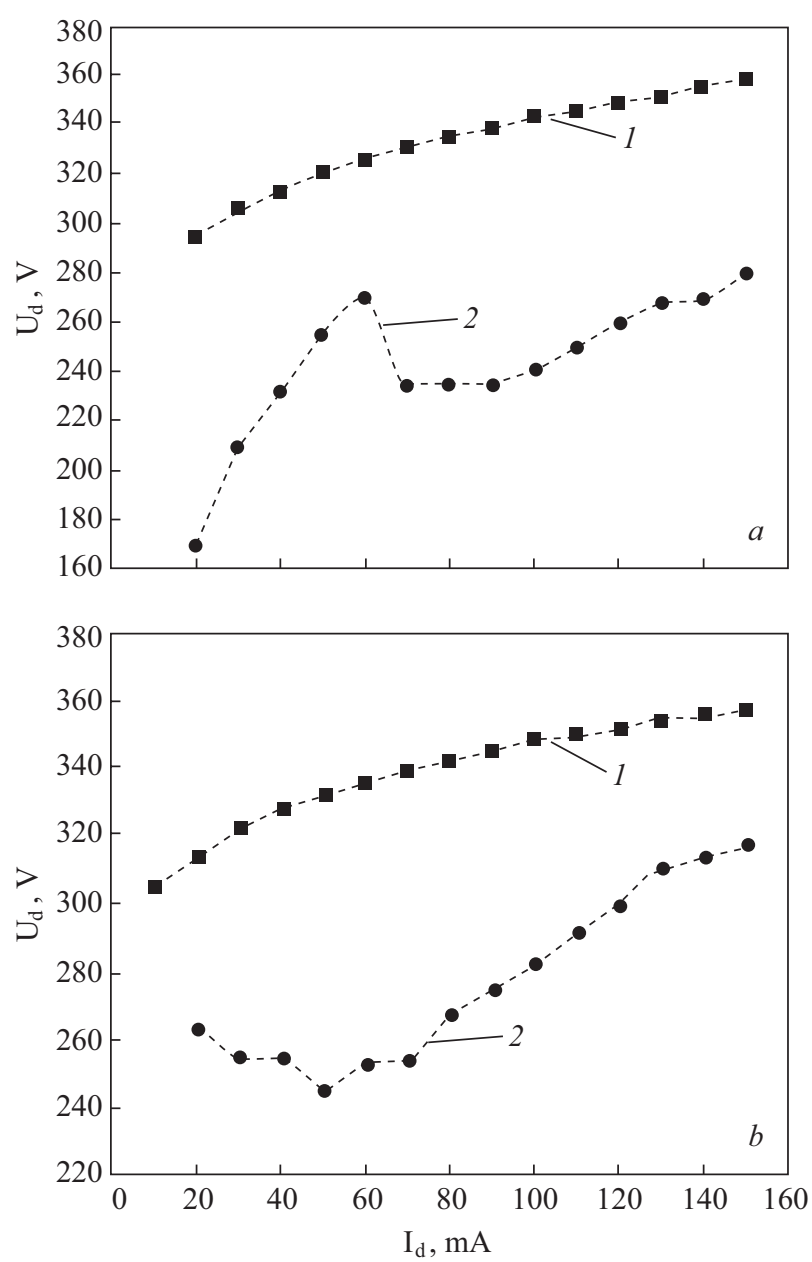

Fig. 2. Glow and combined discharges $\mathrm{CVC}$ at Ar pressure $p=1.7 \cdot 10^{-2}$ Torr $(a)$ and $p=6.7 \cdot 10^{-3}$ Torr $(b)$. The curves for glow discharge and for combined discharge are marked with 1 and 2, respectively

as a microwave source. It operates continuously. The two axial electrodes are used as anodes for DC discharge (Fig. 1, $a$ ), and the chamber wall serves as a cathode. The anodes are made of polished stainless steel 12Kh18N10T disks having $25 \mathrm{~mm}$ in diameter and $1.5 \mathrm{~mm}$ in thickness. The three SS1-SS3 samples made of polished stainless steel 12Kh18N10T are used for studying the chamber wall erosion and placed on the bottom of the chamber. The SS1 and SS2 samples are made of two disks having $25 \mathrm{~mm}$ in diameter and $1.5 \mathrm{~mm}$ in thickness. The SS3 sample is a strip having dimensions $300 \times 50 \mathrm{~mm}$ and thickness of $0.5 \mathrm{~mm}$.
The local plasma characteristics (density and electron temperature) are measured with a single Langmuir probe. The noncontact passive method of optical plasma spectroscopy is used to estimate ion plasma composition. The optical emission spectrum is registered in the range of $214-673 \mathrm{~nm}$ with a spectrometer of SL-40-2-3648 USB SOLAR TII type (the spectral resolution $<0.6 \mathrm{~nm}$ ). The spectral lines are identified according to [26]. The plasma radiation spectrum is recorded through optical fiber line placed at the upper optical window (Fig. 1, $a$ ). The stainless steel outgassing is determined in situ by the thermo-desorption probe method. The method and procedure to determine stainless steel outgassing rate $q$ and the number of monolayers $N$ are described in detail in [27, 28]. The sputtering of the samples SS1-SS3 is measured with the weight loss method, with the use of balance VLR-200, an analog to that described in [25].

Before the experiment, the DSM-1 device is pumped out to a pressure of $\sim 5 \cdot 10^{-6}$ Torr that correspond to the outgassing rate $\sim 10^{-9}$ Torr $\cdot 1 / \mathrm{s} \cdot \mathrm{cm}^{2}$. The working gas is high-purity argon (99.998\%) at a pressure ranging within $10^{-1}-10^{-3}$ Torr. The GD or combined discharge starts inside the device with microwave power supplied from a magnetron generator.

The current-voltage (IV) characteristic (CVC) is measured for both discharges. The typical CVC for the glow and combined discharges are shown in Fig. 2. The discharge current increases, as the voltage grows, in both cases. The discharge voltage is lower in the case of the combined discharge than in the case of the glow one. The CVC analysis has shown that the voltage difference for the whole pressure range of glow and combined discharges (current $100 \mathrm{~mA}$ ) is $\Delta U=70-100 \mathrm{~V}$. The measured electron density is $n_{e} \sim 5 \cdot 10^{8} \mathrm{~cm}^{-3}$ for the glow and the combined discharges. The plasma electron temperature $T_{e}$ is $\approx 10 \mathrm{eV}$ in the case of the glow discharge and $\approx 50 \mathrm{eV}$ in case of the combined discharge. The plasma optical emission spectrum of both discharges (Fig. 3) shows the presence of exited lines of atoms $\mathrm{H}^{*}, \mathrm{Ar}^{*}$ (Ar I), and ions $\mathrm{Ar}^{+*}$ (Ar II). 

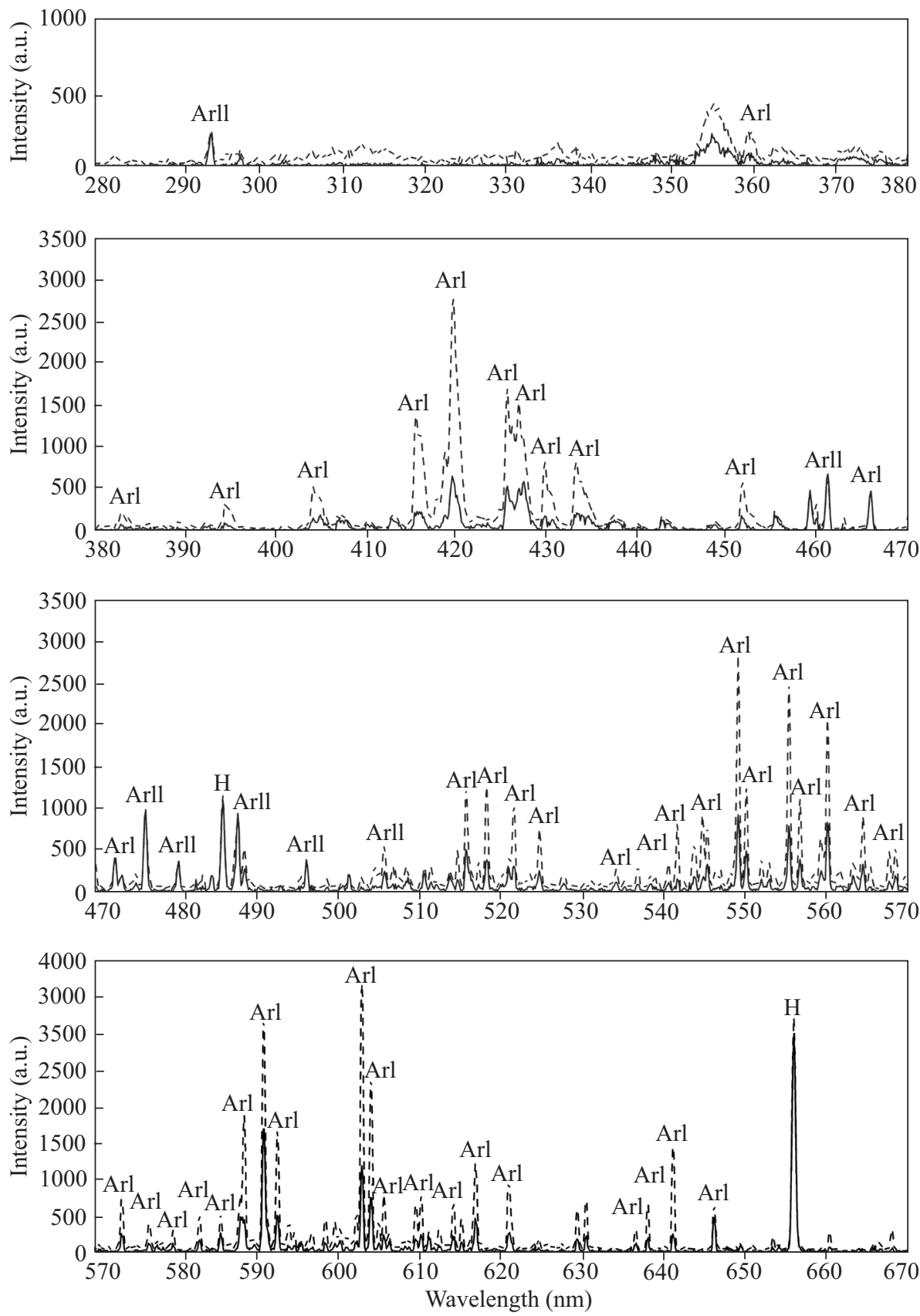

Fig. 3. Emission spectra of glow (solid) and combined (dashed) discharges (Ar pressure $p \approx 7.8 \cdot 10^{-3}$ Torr)

The neutral gas pressure chosen for the wall conditioning and erosion study is $10^{-3}-10^{-2}$ Torr. Two separate experiments to determine the outgassing and stainless steel erosion rates have been carried out for the glow and combined discharges.
The initial conditions are almost the same for both experiments. In both cases, the vacuum chamber is open to atmosphere before the experiments and then the chamber is pumped out. The discharge current is maintained at $100 \mathrm{~mA}$ for both dischar- 


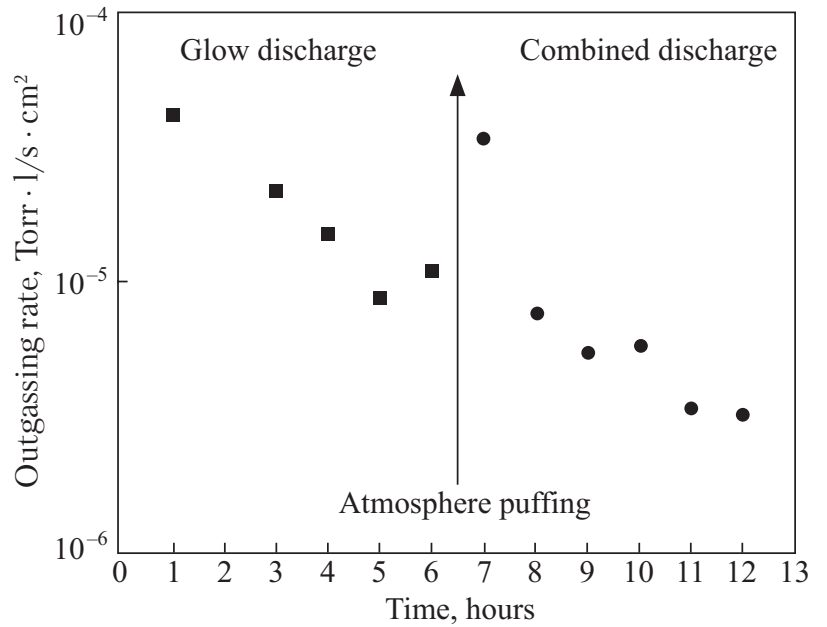

Fig. 4. Specific rate of stainless steel 12Kh18N10T gas emission $\left(300{ }^{\circ} \mathrm{C}\right)$ measured in situ in DSM-1 vacuum chamber depending from vacuum chamber walls conditioning time

ges. This corresponds to the ion current density at the chamber wall $j \approx 12 \mu \mathrm{A} / \mathrm{cm}^{2}$. The duration of plasma conditioning of the chamber walls is 5 hours for each type of discharge. Fig. 4 shows that chamber wall conditioning by the glow discharge decreases the outgassing rate of stainless steel at $300{ }^{\circ} \mathrm{C} 5$ times, from $5.5 \cdot 10^{-5} \mathrm{Torr} \cdot \mathrm{l} / \mathrm{s} \cdot \mathrm{cm}^{2}$ to $1 \cdot 10^{-5}$ Torr $\cdot 1 / \mathrm{s} \cdot \mathrm{cm}^{2}$, whereas, after the chamber wall conditioning by the combined discharge, the outgassing rate decreases to $3 \cdot 10^{-6}$ Torr $\cdot 1 / \mathrm{s} \cdot \mathrm{cm}^{2}$. This means that the combined discharge has a higher efficiency. It should be noted that the ultimate vacuum after several conditioning cycles improves from $\sim 5 \cdot 10^{-6}$ Torr to $(1.5-2) \cdot 10^{-6}$ Torr, and the outgassing rate decreases from $10^{-9} \mathrm{Torr} \cdot 1 / \mathrm{s} \cdot \mathrm{cm}^{2}$ to $8 \cdot 10^{-10}$ Torr $\cdot 1 / \mathrm{s} \cdot \mathrm{cm}^{2}$. The measured stainless steel erosion (sputtering) coefficient is given in Table 1 . The table shows that in the case of glow discharge, the stainless steel erosion coefficient is

Table 1. Stainless Steel Erosion

(Sputtering) Coefficient in Ar Plasma under

Different Plasma Conditioning Conditions $\left(\mathrm{j} \approx 12 \mu \mathrm{A} / \mathrm{cm}^{2} ; 2.4 \cdot 10^{19} \mathrm{ion} / \mathrm{cm}^{2}\right)$

\begin{tabular}{|l|c|c|c|}
\hline $\begin{array}{c}\text { Plasma conditioning } \\
\text { conditions }\end{array}$ & $\begin{array}{c}\text { SS1, } \\
\text { atom/ion }\end{array}$ & $\begin{array}{c}\text { SS2, } \\
\text { atom/ion }\end{array}$ & $\begin{array}{c}\text { SS3, } \\
\text { atom/ion }\end{array}$ \\
\hline Glow discharge & 0.360 & 0.395 & - \\
Combined discharge & 0.203 & 0.305 & 0.190 \\
\hline
\end{tabular}

1.5 times higher than the in case of combined discharge. In [29], it has been stated that the average glow discharge ion energy is $E \approx 0.3 \mathrm{e} U$. In our case, the average ion energy (discharge current $100 \mathrm{~mA}$ ) is $\sim 110 \mathrm{eV}$, in the case of glow discharge, and $\sim 80 \mathrm{eV}$, in the case of combined one. The absolute values of the erosion coefficient (Table 1) for the glow discharge have a good match with the literature data for Fe sputtering caused by $100 \mathrm{eV}$ argon ion $\mathrm{Ar}^{+}$bombardment [30].

As a result, the research has shown good prospects for using combined discharge for wall conditioning in plasma devices. The combined discharge has been realized at Uragan-2M stellarator. This has allowed us to apply the vacuum chamber conditioning technology at big toroidal device and to study the discharge features in the conditions that are relevant for fusion devices.

\section{Combined Discharge in Uragan-2m Stellarator. First Experiments}

Uragan-2M (U-2M) device is a medium-sized stellarator of the torsatron type (Fig. 5) [31, 32]. The device major radius is $R=1.7 \mathrm{~m}$, the average plasma radius is $r_{p l}<24 \mathrm{~cm}$, the toroidal magnetic field is $B_{0}<2.4 \mathrm{~T}$. The vacuum chamber is toroidal with a minor radius of $r_{c}=0.34 \mathrm{~m}$, its volume is $V_{c}=3.879 \mathrm{~m}^{3}$ (without vacuum ports), the torus inner surface is $S=22.819 \mathrm{~m}^{2}$. The chamber has 48 ports that are used for diagnostic devices, gas puffing and vacuum pumping. The vacuum chamber is pumped with three turbo-molecular pumps TMN-500 at a pumping rate of $500 \mathrm{l} / \mathrm{s}$. The fore-vacuum pumping is done by a fore-vacuum pump at a pumping rate of $63 \mathrm{l} / \mathrm{s}$.

The glow discharge and microwave systems have been developed, constructed, manufactured, and installed at U-2M to realize the combined discharge. The glow discharge system consists of four identical water cooled electrodes (anodes) and a power source. The vacuum chamber wall serves as cathode. The anodes are cylindrical rods having $59 \mathrm{~cm}$ in length and $2 \mathrm{~cm}$ in diameter (Fig. 6, $a$ ). They are made of stainless steel. The area of cur- 


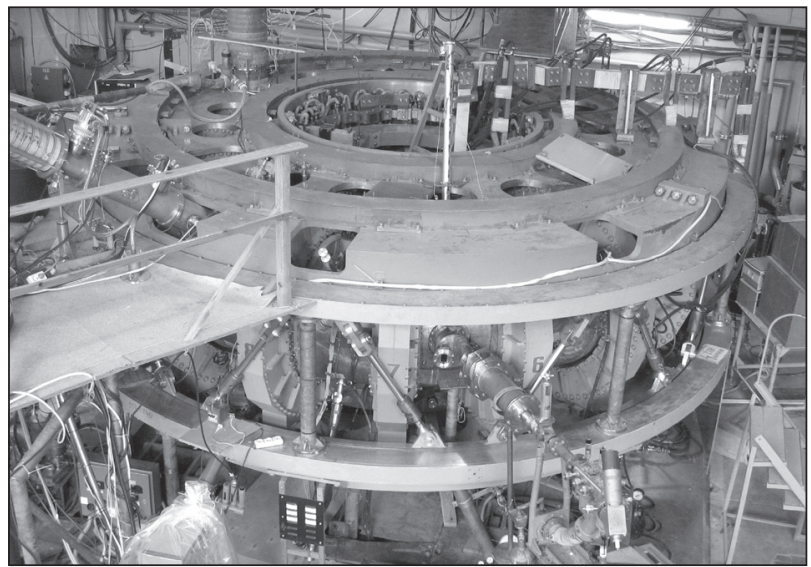

$a$

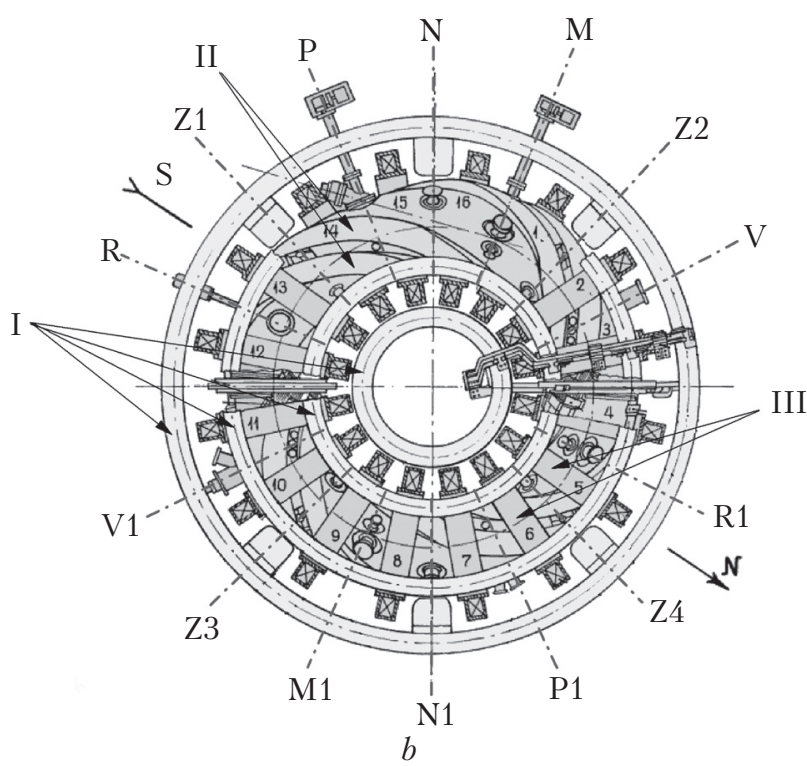

Fig. 5. U-2M photo $(a)$ and scheme $(b)$. I - poloidal coils; II - helical coils; III - toroidal field coils $(1-16)$

rent receiving surface of a single anode is $392 \mathrm{~cm}^{2}$, and for the four anodes it totals $1560 \mathrm{~cm}^{2}$. The electrodes (anodes) are installed at U-2M I crosssections Z1, Z2, Z3, and Z4 (Fig. 5, b). The distance from the electrode to the outer side of the last closed surface is $3 \mathrm{~cm}$ at $K_{\varphi}=0.32$. The universal power source UDZh-1 is used for the discharge. Its output voltage may vary from 20 to $610 \mathrm{~V}$, with a maximum current of $600 \mathrm{~mA}$. The power source with an output voltage of $1.9 \mathrm{kV}$ and a maximum current of $5 \mathrm{~A}$ is used for higher discharge voltages and currents. The anode voltage

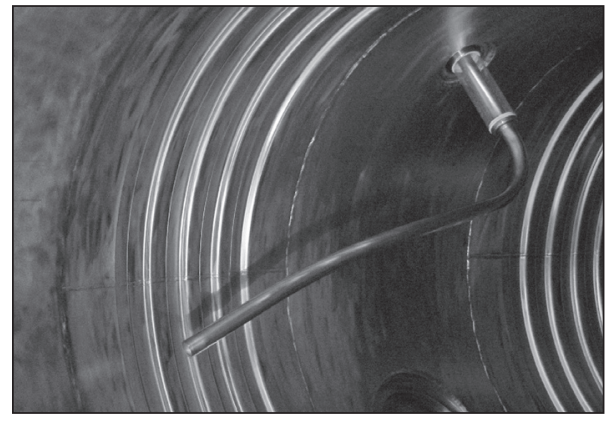

$a$

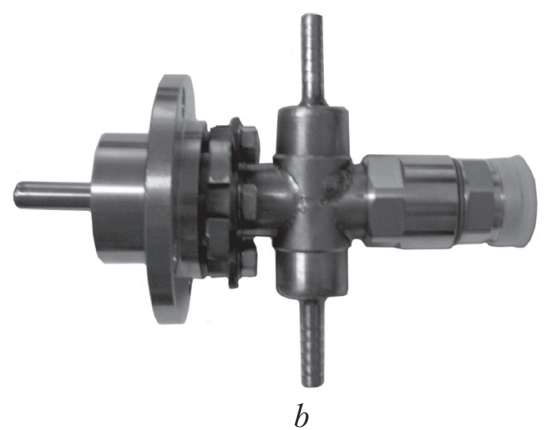

Fig. 6. Electrode (anode) photo in U-2M vacuum chamber $(a)$, whip antenna general view $(b)$

is measured with volt-meters and the total anode current is measured with a milliampere-meter.

The microwave power is fed into the vacuum chamber with a whip antenna (Fig. 6, b) that is designed, made, and installed into $45 \mathrm{~mm}$ vacuum port (Fig. 6,c). The antenna whip length is quarter of the wavelength. The antenna is water cooled. The microwave system scheme is shown in Fig. 7. M 105-1 magnetron is used as microwave generator. It operates at a frequency of $2.45 \mathrm{GHz}$ $(\lambda=12.2 \mathrm{~cm})$. The magnetron nominal power is $600 \mathrm{~W}$. The magnetron operates in continuous regime with fan air cooling. The microwave power is transferred to antenna through the coaxial transmission line. The transmission line matching is varied by short-circuiting pistons; $10 \mathrm{~m}$ long coaxial cable DRAKA RFA7/8"-50L (impedance $50 \mathrm{Ohm}$ ) is used as transmission line. The attenuation coefficient for cable in $2.4-2.6 \mathrm{GHz}$ range is $0.0648-0.0678 \mathrm{~dB} / \mathrm{m}$. The cable may transmit a continuous power of $1.4 \mathrm{~kW}$ at a frequency of $2.4-2.6 \mathrm{GHz}$. 


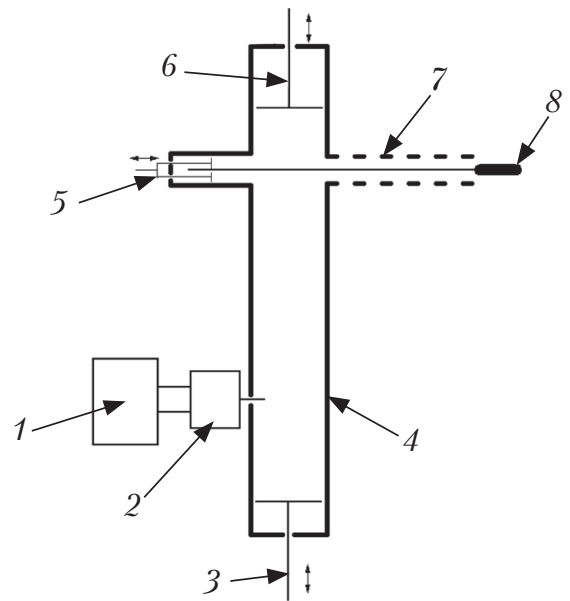

Fig. 7. Microwave system scheme. 1 - Microwave magnetron power source; 2 - Microwave magnetron; 3, 5, 6- pistons; 4 - coaxial-waveguide junction; 7 - feeder line (coaxial cabel); 8 - whip antenna

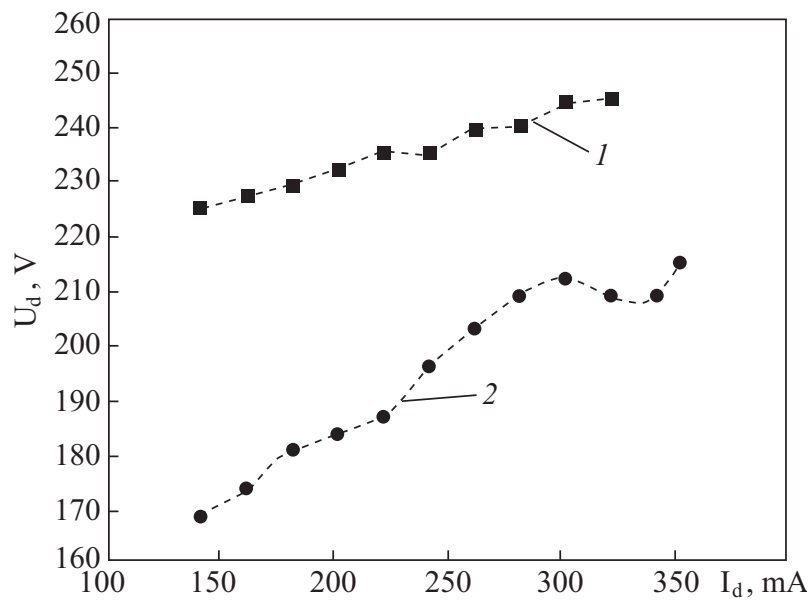

Fig. 8. Volt-ampere characteristics: 1 - d.c. discharge, $2-$ combined microwave discharge $(f=2.45 \mathrm{GHz})$ and d.c. discharge (Ar, $p=4,2 \cdot 10^{-2}$ Torr)

The glow discharge research experiments have been carried out at U-2M without a magnetic field. The vacuum chamber residual pressure is $p_{\text {o.p. }}=1.5 \cdot 10^{-7}$ Torr. The vacuum volume is filled with high purity Ar (99.998\%) as working gas, at a pressure of $7.5 \cdot 10^{-4}-0.1$ Torr. Since the cathode is shaped as hollow torus (U-2M vacuum chamber walls), the glow discharge may be treated as hollow cathode discharge. The hollow cathode discharge is generally a self-sustained gas discharge with cold cathodes [33, 34]. One of the hollow discharge features is electric field non-uniformity in the discharge gap. Firstly, the discharge ignition voltage and the CVC have been determined. The charge ignition voltage is $564 \mathrm{~V}$ (the left Paschen curve branch) and $259 \mathrm{~V}$ (the right Paschen curve branch), at a pressure ranging within $4.5 \cdot 10^{-3}-9.8 \cdot 10^{-2}$ Torr with a minimal value of $\mathrm{U}_{\min } \approx 253 \mathrm{~V}\left(\mathrm{p}=6.8 \cdot 10^{-2}\right.$ Torr $)$. The CVC has a slight positive slope like in the case of hollow cathode discharges [34]. For example, the voltage is equal to $264 \mathrm{~V}$ at a pressure of 4.5 . $10^{-3}$ Torr and a discharge current of $40 \mathrm{~mA}$, and to $350 \mathrm{~V}$ at $500 \mathrm{~mA}$. The discharge voltage is $202 \mathrm{~V}$ at a current of $40 \mathrm{~mA}$ and $237 \mathrm{~V}$ at $440 \mathrm{~mA}$ and pressure $p=5 \cdot 10^{-2}$ Torr. The visible plasma glow has no pressure dependence and is observed in the whole chamber.

A single electrode installed at Z1 cross-section is used as anode in the combined discharge experiments (Fig. 5, $b$ ). The CVC is measured at a constant pressure, during the DC and combined discharge. The self-sustained DC discharge is ignited at the first stage and its CVC is measured. The voltage for single anode matches the earlier measured voltage for the four anodes. The CVC shape for the single anode (Fig. 8, curve 1), discharge voltage, and current are close to already measured ones for the four anodes. The microwave power is fed into vacuum vessel during burning DC discharge at the second stage. The discharge voltage decreases at the moment of power input. Then, the combined discharge CVC is measured (Fig. 8, curve 2). The combined discharge voltage decreases by $\Delta U=32-57 \mathrm{~V}$. The discharge voltage increases to the already measured value without microwave, when microwave power is off. The minimal experimentally measured $\Delta U$ value is $10-20 \mathrm{~V}$ and depends on argon pressure and input power. The research has shown the possibility of combined discharge implementation in a big chamber with a volume of $\sim 4 \mathrm{~m}^{3}$ and a rather small input power.

\section{Conclusion}

From the research on the combined RF and DC discharge the following may be concluded: 
- the anode voltage of combined discharge is lower than in the case of glow one;

- the stainless steel $12 \mathrm{Kh} 18 \mathrm{~N} 10 \mathrm{~T}$ erosion coefficient is about 1.5 times less in the case of combined discharge than in the case of glow one;

- the thermal desorption diagnostic of wall conditions in the DSM-1 has shown better efficiency with the combined discharge: the glow discharge conditioning during 5 hours causes 5 times decrease in stainless steel 12Kh18N10T outgassing rate, while the combined discharge conditioning under the same initial conditions causes 15 times decrease in the outgassing rate.
- The combined discharge may be realized in both small and big vacuum chambers.

Further improvements in the combined discharge efficiency in wall conditioning are associated with increasing microwave power that is quite small in our experiments, especially, in the case of U-2M.

As a result, the research has shown good prospects for using the combined discharge for plasma devices walls conditioning. The research results have been implemented at Uragan-2M and will be proposed for EUROfusion devices.

The research has been done within the Priority $R$ EंD Support program, project № 25/22-2019.

\section{REFERENCES}

1. Shimada, M., Pitts, R. (2011). Wall conditioning on ITER. Journal of Nuclear Materials, 415(1), 5-19. doi: 10.1016/j. jnucmat.2010.11.085.

2. Douai, D., Kogut, D., Wauters, T., Brezinsek, S., Hagelaar, G. J. M., Hong, S. H., Lomas, P. J., Lyssoivan, A., Nunes, I., Pitts, R. A., Rohde, V., de Vries, P. C. (2015). JET EFDA Contributors, The ASDEX-Upgrade Team. Wall conditioning for ITER: Current experimental and modeling activities. Journal of Nuclear Materials, 463, 150-156. doi: 10.1016/j. jnucmat.2014.12.034.

3. Dylla, H. F. (1980). A review of the wall problem and conditioning techniques for tokamaks. Journal of Nuclear Materials, 93, 61-74. doi: 10.1016/0022-3115(80)90303-7.

4. Winter, J. (1989). Wall conditioning of fusion devices by reactive plasmas. Journal of Nuclear Materials, 161(3), 265330. doi: 10.1016/0022-3115(89)90466-2.

5. Winter, J. (1996). Wall conditioning in fusion devices and its influence on plasma performance. Plasma Phys. Control. Fusion, 38, 1503-1542. doi: 10.1088/0741-3335/38/9/001.

6. Wauters, T., Brakel, R., Brezinsek, S., Dinklage, A., Goriaev, A., Laqua, H. P., Marsen, S., Moseev, D., Stange, T., Schlisio, G., Sunn Pedersen, T., Volzke, O., Wenzel, U. (2018). Wall conditioning by ECRH discharges and He-GDC in the limiter phase of Wendelstein 7-X. Nuclear Fusion, 58(6), 066013-066020. doi: 0000-0002-7213-3326.

7. Wauters, T., Goriaev, A., Alonso, A., Baldzuhn, J., Brakel, R., Brezinsek, S., Dinklage, A., Grote, H., Fellinger, J., Ford, O. P., König, R., Laqua, H., Matveev, D., Stange, T., Vanó, L. (2018). Wall conditioning throughout the first carbon divertor campaign on Wendelstein 7-X. Nuclear Materials and Energy, 17, 235-241. doi: 10.1016/j.nme.2018.11.004

8. De La Cal, E., Gauthier, E. (2005). Review of radio frequency conditioning discharges with magnetic fields in superconducting fusion reactors. Plasma physics and controlled fusion, 47, 197-218. doi: 10.1088/0741-3335/47/2/001.

9. Wauters, T., Borodin, D., Brakel, R., Brezinsek, S., Brunner, K. J., Buermans, J., Coda, S., Dinklage, A., Douai, D., Ford, O., Fuchert, G., Goriaev, A., Grote, H., Hakola, A., Joffrin, E., Knauer, J., Loarer, T., Laqua, H., Lyssoivan, A., Moiseenko, V., Moseev, D., Ongena, J., Rahbarnia, K., Ricci, D., Rohde, V., Romanelli, S., Sereda, S., Stange, T., Tabarés, F. L., Vanó, L., Volzke, O., Wang, E. (2020). Wall conditioning in fusion devices with superconducting coils. Plasma physics and controlled fusion, 62, 034002-034014. doi: 10.1088/1361-6587/ab5ad0.

10. Sergienko, G., Lyssoivan, A., Philipps, V., Kreter, A., Schulz, C., Huber, A., Esser, H. G., Hu, J. S., Freisinger, M., Reimer, H., Samm, U. (2009). Ion cyclotron wall conditioning in reactive gases on TEXTOR. Journal of nuclear materials, 390, 979-982. doi: 10.1016/j.jnucmat.2009.01.252.

11. Nazarov, N. I., Plyusnin, V. V., Ranyuk, T. Yu. (1987). Cleaning of surfaces by plasma in the Uragan-3 torsatron. Fizika Plazmy, 13, 1511-1515 [in Russian].

12. Moiseenko, V. E., Burchenko P. Ya., Chechkin, V. V., Chernyshenko, V. Ya., Grigor`eva, L. I., Hartmann, D., Koch, R., Konovalov, V. G., Lozin, A. V., Lyssoivan, A. I., Pashnev, V. K., Shapoval, A. N., Shvets, O. M., Skibenko, A. I., Stadnik, Yu. S., Tereshin, V. I., Voitsenya, V. S., Volkov, E. D. (2009). Wall Conditioning RF Discharges in Uragan-2M Torsatron. 36th EPS Conference on Plasma Phys. (June 29 - July 3, 2009, Sofia). ECA, 33E, P-5.199. 
13. Lozin, A. V., Moiseenko, V. E., Grigor'eva, L. I., Kozulya, M. M., Kulaga, A. E., Lysoivan, A. I., Mironov, Yu. K., Pavlichenko, R. O., Romanov, V. S., Chernyshenko, V. Ya., Chechkin, V. V. (2013). Cleaning of inner vacuum surfaces in the Uragan-3M facility by radio-frequency discharges. Plasma Physics Reports, 39(8), 624-631. doi: 10.1134/S1063780X13070052.

14. Moiseenko, V. E., Lozin, A. V., Chechkin, V. V., Chernyshenko, V. Ya., Grigor'eva, L. I., Kramskoi, Ye. D., Korovin, V. B., Kozulya, M. M., Lyssoivan, A. I., Schebetun, A. V., Shapoval, A. N., Shtan', A. F., Solodovchenko, S. I., Voitsenya, V. S., Garkusha, I. E. (2014). VHF discharges for wall conditioning at the Uragan-2M torsatron. Nuclear Fusion, 54, 033009033014. doi: 10.1088/0029-5515/54/3/033009.

15. Lozin, A. V., Moiseenko, V. M., Kozulya, M. M., Kramskoj, E. D., Korovin, V. B., Yevsyukov, A. V., Grigor'eva, L. I., Beletskii, A. A., Shapoval, A. N., Makhov, M. M., Krasyuk, A. Yu., Baron, D. I. (2016). Continuous wall conditioning VHF discharge without magnetic field in a toroidal device. Problems of Atomic Science and Technology, 6, 60.

16. Bondarenko, M. N., Glazunov, G. P., Konotopskiy, A. L., Lozin, A. V., Moiseenko, V. E., Aksenov, N. N., Garkusha, I. E., Herashchenko, S. S., Makhlaj, V. A. (2018). Influence of different types of hydrogen treatment on hydrogen retention and release from 12kh18n10t steel. Problems of Atomic Science and Technology, 6, 50.

17. Lobov, G. D., Eremeyev, V. I. (1961). Some effects accompanying detection in a gas discharge. Radiotekh. Elektron., 6, 286 [in Russian].

18. Kopeika, N. S., Farhat, N. H. (1975). Video detection of millimeter waves with glow discharge tubes: Part I-Physical description; part II-Experimental results. IEEE transactions on electron devices, 22(8), 534-548. doi: 10.1109/T-ED. 1975.18175.

19. Rosenberg A., Ben-Aryeh, Y., Politch, J. and Felsteiner, J. (1982). Amplification, cnrrent-voltage variations, and refraction in the interaction between millimeterwave radiation and the glow-discharge plasma Physical Review A, 25, 11601177. doi: 10.1103/PhysRevA.25.1160.

20. Lebedev, Yu. A., Tatarinov, A. V., Epshtein, I. L. (2007). An electrode microwave discharge in a static field. High Temperature, 283-290. doi: 10.1134/S0018151X07030017.

21. Lebedev, Yu. A., Epshtein, I. L., Yusupova, E. V. (2014). Influence of a DC field on the near-electrode zone of nonuniform microwave discharge in hydrogen. High Temperature, 52, 150-156. doi: 10.7868/S0040364414020136.

22. Burchenko, P. Ya., Volkov, E. D., Gribanov, Yu. A., Nekludov, I. M., Opalev, O. A., Rubtsov, K. S. Rybalko, I. F., Ternopol, A. M. (1985). The study of materials erosion in a discharge with oscillating electrons. Sov.J. Tech. Phys., 55(11), 20972288 [in Russian].

23. Glazunov, G. P., Volkov, E. D., Baron, D. I., Dolgiy, A. P., Konotopskiy, A. L., Hassanein, A. (2003). Effect of Low/High Hydrogen Recycling Operation on Palladium Sputtering under Steady State Plasma Impact. Physica Scripta, 103, 8992. doi: 10.1238/Physica.Topical.103a00089.

24. Glazunov, G. P., Bondarenko, M. N., Konotopskiy, A. L., Volkov, E. D. Erosion behavior of tungsten coatings in magnetron type discharges with hot cathode. (2008). Problems of Atomic Science and Technology, 14(6), 107-109.

25. Glazunov, G. P., Andreev, A. A., Bondarenko, M. N., Konotopskiy, A. L., Moiseenko, V. E., Stolbovoy, V. A. (2011). Erosion vacuum-arc TiN coatings and stainless steel under impact of steady state plasma of magnetron type discharges. Physical surface engineering, 9(3), 250-255 [in Russian].

26. Kramida, A., Ralchenkob, Yu., Reader, J. and NIST ASD Team (2019). NIST Atomic Spectra Database (version 5.7.1). National Institute of Standards and Technology, Gaithersburg, MD. doi: 10.18434/T4W30F.

27. Glazunov, G. P., Baron, D. I., Moiseenko, V. E., Bondarenko, M. N., Konotopskiy, A. L., Lozin, A. V., Lyssoivan, A. I., Wauters, T., Garkusha, I. E. (2018). Characterization of wall conditions in Uragan-2M stellarator using stainless steel thermal desorption probe. Fusion Engineering and Design, 137, 196-201. doi: 10.1016/j.fusengdes.2018.09.010.

28. Glazuno, G. P., Baron, D. I., Bondarenko, M. N., Moiseenko, V. E., Garkusha, I. E., Konotopskiy, A. L., Lozin, A. V., Lyssoivan, A. I., Wauters, T. (2018). In situ quantification of plasma facing surface conditions in the Uragan-2M torsatron. Problems of Atomic Science and Technology, 1(107), 12-16.

29. Babad-Zakhryapin, A. A., Kuznetsov, G. D. (1982). Radiation-stimulated chemical-thermal treatment. Moscow: Energy Publishing House, 96 p. [in Russian].

30. Laegreid, N., Wehner, G.K. (1961). Sputtering yields of metals for Ar+ and Ne+ ions with energies from 50 to $600 \mathrm{eV}$. J. Appl. Phys., 32(4), 365-369. doi: 10.1063/1.1736012.

31. Pavlichenko, O. S. (1993). First results from the 'URAGAN-2M' torsatron. Plasma physics and controlled fusion, 35, 223. doi: 10.1088/0741-3335/35/SB/018.

32. Moiseenko, V. E., Lozin, A. V., Kozulia, M. M., Mironov, Yu. K., Romanov, V. S., Konovalov, V. G., Shapoval, A. N. (2017). Alfven plasma heating in stellarator Uragan-2M. Ukrainian Journal of Physics, 62, 311. doi: /10.15407/ujpe62.04.0311.

33. Moskalev, B. I. (1969). Razryad s polyim katodom. Moscow: Energy Publishing House, 184 p. [in Russian]. 
34. Kolobov, V. I., Metel, A. S. (2015). Glow discharges with electrostatic confinement of fast electrons.J. Phys. D: Appl. Phys., 48, 233001. doi: 10.1088/0022-3727/48/23/233001.

Received 08.10.2020

Revised 05.11.2020

Accepted 29.03.2021

Ю.В. Ковтун (https://orcid.org/0000-0003-4948-0896),

Г.П. Глазунов (https://orcid.org/0000-0002-8895-927X),

B.C. Моісеєнко (https://orcid.org/0000-0001-9431-5617),

C.M. Мазніченко (https://orcid.org/0000-0002-4548-370X),

М.М. Бондаренко (https://orcid.org/0000-0001-5783-9788),

А.Л. Конотопський (https://orcid.org/0000-0002-1622-6376),

Є.В. Сюсько (https://orcid.org/0000-0002-0789-7100),

I.K. Тарасов (https://orcid.org/0000-0001-8025-645X),

А.М. Шаповал (https://orcid.org/0000-0002-4521-7217),

А.В. Лозін (https://orcid.org/0000-0002-8423-0078),

В.Б. Коровін (https://orcid.org/0000-0001-8677-1073),

Є.Д. Крамской (https://orcid.org/0000-0002-3621-468X),

М.М. Козуля (https://orcid.org/0000-0003-3854-7047),

Д.І. Барон (https://orcid.org/0000-0001-5971-1243),

B.M. Листопад (https://orcid.org/0000-0001-7768-0495),

А.Ю. Красюк (https://orcid.org/0000-0003-4347-310X)

Інститут фізики плазми,

Національний науковий центр Харківський фізико-технічний інститут

вул. Академічна, 1, Харків, 61108 ,

+380 57335 3530, garkusha@ipp.kharkov.ua

РОЗРОБКА ТЕХНОЛОГІЇ ЧИЩЕННЯ ВАКУУМНИХ

ПОВЕРХОНЬ ПЛАЗМОЮ ВИСОКОЧАСТОТНОГО РОЗРЯДУ

В КОМБІНАЦІЇ З РОЗРЯДОМ ПОСТІЙНОГО СТРУМУ

Вступ. В експериментальних дослідженнях високотемпературної плазми, спрямованих на вирішення проблем керованого термоядерного синтезу, важливим питанням $є$ необхідність зменшення потоків легких та важких домішок до об'єму утримання плазми. Підготовка внутрішніх вакуумних поверхонь є невід’ємною частиною функціонування термоядерних установок, а розробка ефективних сценаріїв щодо підготовки поверхонь є нагальною потребою.

Проблематика. У застосовуваної сьогодні технології чищення внутрішніх поверхонь вакуумної камери за допомогою жевріючого розряду є досить суттєвий недолік - розпилення матеріалів у вакуумній камері. Для чищення внутрішніх вакуумних поверхонь також використовується плазма, створена високочастотним розрядом, але їі ефективність обмежується низькою енергією іонів.

Мета. Розробка технології чищення вакуумних поверхонь плазмою високочастотного розряду в комбінації з розрядом постійного струму.

Матеріали й методи. Для визначення зарядового стану іонів та елементного складу плазми використано безконтактний пасивний метод оптичної плазмової спектроскопії. Швидкість газовиділення нержавіючої сталі in situ визначали діагностичним методом на основі термодесорбційного зонда. Коефіцієнт розпилення зразків виміряно методом вагових втрат.

Результати. Дослідження показали, що анодна напруга комбінованого розряду є нижчою, ніж у жевріючому розряді; швидкість ерозії нержавіючої сталі 12Х18Н10Т приблизно в 1,5 рази менший при комбінованому розряді, ніж у жевріючому розряді; термодесорбційна діагностика стану стінки в ДСМ-1 показала, що чистка комбіновваним розрядом продемонструвала кращу ефективність ніж жевріючим розрядом. Запропонована розробка є оригінальною та не має аналогів у світі.

Висновки. Наведені результати дослідження показали перспективу використання комбінованого розряду для чищення стінок у плазмових пристроях, що відкриває широкі можливості застосування розробленої технології на основі комбінованого розряду для чищення великих тороїдальних вакуумних камер.

Ключові слова: плазма, жевріючий розряд, мікрохвильовий розряд, стеларатор, вакуум. 